DOI https://doi.org/10.30525/978-9934-588-63-1.18

\title{
ВИКЛИКИ ПРАВОВІЙ БЕЗПЕЦ СУСПІЛЬСТВА В УКРАЇНІ
}

\author{
Корж I. Ф.
}

\section{ВСТУП}

Якщо розглядати нинішнє становище суспільства в Україні, то доцільно зазначити, що воно знаходиться в пошуку свого місця в соціальних умовах, які склалися, і фактично маргіналізоване. Тобто, відійшовши від відповідних ознак так званого «соціалістичного» суспільства, 3 його відповідними внутрішніми зв’язками між різними соціальними групами, нинішне українське суспільство можна характеризувати як таке, в якому утворилися фактично антагоністичні соціальні групи (олігархи, невеличка група заможних громадян і середнього класу, великий прошарок бідних, певна кількість знедолених). Йому притаманні: розрив традиційних зв'язків між людьми; вироблення індивідами ярко виражених об'єктивних ознак належності до тої чи іншої соціальної групи; перекручені естетичні, етичні, правові, фізіологічні та інші загальнолюдські норми і цінності; перетворення людей на духовних i соціальних люмпенів, повністю залежних від непередбачуваних дій влади, та фактично безконтрольних демагогів і авантюристів.

Значна частина громадян бере участь у страйках, демонстраціях. Причому участь людей у зазначених громадських акціях пов'язана із соціальними проблемами (невиплата заробітної плати, пенсій, низькі заробітні плати; невідповідність дій державної влади, місцевого самоврядування положенням Конституції та законам України тощо), значною мірою породженими безпосередньо владою, насамперед у частині правового регулювання тих чи інших актуальних для суспільства питань. Виникає актуальна проблема сьогодення - виникнення загроз суспільству, його життєво важливим інтересам. А тому необхідне наукове дослідження питання виникнення та актуальності загроз суспільству, насамперед у правовій сфері, нинішнього стану правової безпеки суспільства в Україні.

Питання стану прав i свобод громадян та суспільства в Україні порушене у значній кількості наукових робіт. Цьому питанню приділяли увагу В. Авер'янов, М. Антонович, Ф. Брецько, А. Булгакова, В. Буткевич, П. Добродумов, А. Лобода, В. Речицький, П. Рабінович, С. Серьогіна, Ю. Тодика, М. Цвік, О. Чуб, Г. Шмельова та інші. Водночас концептуальний характер дослідження цього права насамперед через призму 
правової безпеки суспільства, особливостей ऑiі здійснення вимагає продовження концептуальних наукових досліджень.

Метою дослідження $є$ розкриття питання стану правового регулювання функціонування суспільства в Україні, проблем правового регулювання, причин їх виникнення, змісту терміна «правова безпека суспільства», пропозиція шляхів вирішення проблем у сфері правової безпеки суспільства.

\section{1. Стан законотворчості в Україні як ознаки правової безпеки суспільства}

Події 2004 року, а потім 2014 року в Україні вселили в суспільство певний оптимізм щодо подальшого напряму розвитку України як правової, соціальної, демократичної держави. Однак, як і після 2004 року, так і після 2014 року багато українських громадян зневірилися в політиках, а тому якщо і брали участь у різних акціях на підтримку того чи іншого політичного діяча, то лише за суму певної винагороди. А вибори Глави держави та вибори до парламенту показали, що утворився значний прошарок людей, які або ігнорували згадані вибори, або ж голосували за так званим «приколом», коли обирали тих, хто був альтернативою нинішнім політикам і політикам минулого.

Таким чином, нині залишається низькою, за певним винятком, активність громадян у громадському житті, що негативно впливає на становлення демократичного суспільства.

У рамках демократичного устрою суспільство і влада мають бути зацікавлені в напрацюванні діалогу та партнерства, підвищенні ефективності взаємодії. Цілком зрозуміло, що сучасне розвинуте суспільство повинно мати належні умови для забезпечення свободи думки і слова, вільного вираження поглядів і переконань, участі в управлінні державними справами. Без зазначеного державна влада не спроможна створити можливості функціонування демократії в країні. Лише в поєднанні з безпосередньою та представницькою демократією зазначені умови сприяють успішній модернізації сучасного життя, європейської інтеграції та сталого розвитку. Тому цілком логічним $є$ питання: чи національне право забезпечує належним чином створення таких умов для українського суспільства і чи правова безпека для українського суспільства знаходиться на належному рівні?

Аналіз національного права в Україні дає підстави стверджувати, що його положення $\mathrm{y}$ процесі реформування національної системи законодавства як умови підвищення функціональності правової системи, а також запровадження інтеграційних процесів європейської спрямованості 
загалом мають на меті утвердження в Україні демократичних принципів народовладдя. Наглядним свідченням зазначеного $\epsilon$ зміст нинішньої Конституції України, яку визнають як одну 3 найдемократичніших конституцій. Тому можна стверджувати, що Україна належить до більшості країн світу - держав соціально-демократичної орієнтації, які прагнуть стати правовими.

Однак, враховуючи нинішне глибоке соціальне розшарування суспільства, високий рівень корупції в державі, велику кількість скарг українських громадян на незаконні дії державної влади в Свропейському суді з прав людини тощо, можна констатувати, що дотримання права в українському суспільстві та державі знаходиться в неналежному стані, а це вказує на проблеми зі станом правової безпеки суспільства.

Оскільки найвищою соціальною цінністю правової держави є людина, яка $є$ безпосередньо складовою частиною суспільства загалом, то для повної і всебічної охорони і захисту прав людини необхідні акти, що чітко закріплюють взаємовідносини держави й особи, сприяють зміцненню законності та правопорядку в суспільстві. Серед системи актів законодавства провідну роль відіграє закон як найвищий за юридичною силою нормативно-правовий акт єдиного органу законодавчої влади в країні. Як зазначено в загальній теорії права та юридичній науковій довідковій літературі, закон - «нормативно-правовий акт вищої юридичної сили, прийнятий відповідно до встановленої процедури парламентом або безпосередньо народом, який регулює найважливіші суспільні відносини» ${ }^{1}$.

Відповідно до загальної теорії права, доктринальні і структурні розбіжності між основними правовими сім'ями зумовлюють різні підходи до концепції поняття «закон». У країнах англо-американського права розрізняють поняття «закон» у широкому значенні - як будь-якої писаної чи неписаної норми, що створюється законодавчою і виконавчою владою, i у вузькому (юридичному) значенні - як акта, що походить від парламенту. У країнах романо-германського права поняття «закон» вживається в матеріальному і формальному значенні. У матеріальному сенсі «законом» називають будь-який акт, що містить правові приписи загального характеру i ухвалюється органами державної влади. У формальному розумінні «закон» - це нормативно-правовий акт вищої юридичної сили, прийнятий органом законодавчої влади відповідно до встановленої процедури. Оскільки правова система України тяжіє до романо-германської правової

\footnotetext{
${ }^{1}$ Велика українська юридична енциклопедія : у 20 т. / ред. кол. : О.В. Петришин (голова) та ін.; Нац. акад. прав. наук України; Ін-т держави і права імені В.М. Корецького НАН України; Нац. юрид. ун-т імені Ярослава Мудрого. Харків, 2017. Т. 3 : Загальна теорія права. 952 с.
} 
сім’ї, більш поширеним у вітчизняній юридичній науці є поняття «закон» у формальному значенні.

Закон в Україні приймається Верховною Радою України - парламентом, який є єдиним органом законодавчої влади в Україні (ст. 75), і прийняття законів є одним із повноважень парламенту (ст. 85) ${ }^{2}$, або приймається безпосередньо народом (шляхом референдуму). Закон регулює найбільш значущі, ключові суспільні відносини, встановлює їх відправні засади (ст. 92 Конституції України) і має вищу юридичну силу. Інші нормативноправові акти приймаються органами державної влади та органами місцевого самоврядування i, як і закон, мають відповідати Конституції України.

Зазначене має важливе значення для забезпечення правової безпеки суспільства, а невідповідність зазначеному свідчить про загрози i небезпеки належному функціонуванню права в державі. На жаль, в Україні $\epsilon$ вагомі підстави для ствердження того, що рівень законності, правозастосування, правосвідомості українського суспільства, включаючи посадових і службових осіб публічної влади, не відповідає зазначеному у ст. 1 Конституції щодо правового, соціального та демократичного статусу держави, підтвердженням чого, своєрідним лакмусовим папірцем, $\epsilon$ високий рівень корупції, глибоке соціальне розшарування населення в державі, рекордна кількість скарг українських громадян до Європейського суду щодо порушень їхніх прав із боку державної влади.

3 огляду на зазначені факти, можна зробити висновок, що, незважаючи на високий рівень формалізації правового життя в Україні (прийняття Конституції України на основі загальновизнаних міжнародних норм права, відповідність в основному прийнятих законів положенням Конституції України, проведення в Україні за допомоги міжнародної демократичної спільноти різнобічних реформ тощо), українському суспільству притаманні як відкриті, так і латентні загрози і небезпеки його правовій безпеці.

Зазначене пояснюється тим, що, по-перше, на думку багатьох дослідників, в останні десять років в Україні склалася певна негативна ситуація у сфері законотворчої діяльності. У багатьох країнах розробка законів розглядається як особлива сфера професійної діяльності, що вимагає спеціальних знань і особливих професійних якостей. Цілком зрозуміло, що ті, хто готує закони, повинні мати юридичну освіту і певний досвід роботи за фахом, оскільки якість закону значною мірою залежить від професійної компетентності його розробників. Розуміння загальних принципів правового регулювання, детальне знання ієрархії нормативних

\footnotetext{
${ }^{2}$ Конституція України від 26.06.1996 р. Відомості Верховної Ради України. 1996. № 30. Ст. 141.
} 
актів, специфіки регламентації певних відносин, взаємозв'язку процесуальних і матеріальних норм, володіння юридичною мовою, що дає змогу створювати чіткі нормативні формулювання, дотримання принципів ясності, простоти і правильної організації юридичного тексту, увага до деталей - все це необхідні передумови для створення добре напрацьованого документа.

Для розробки законопроекту потрібно мати певні особистісні якості. Ясність думки, аналітичний розум, володіння мовою, здатність висловлювати думки на папері, вміння аргументувати і відстоювати свою позицію, творчу уяву і здоровий глузд, прагматизм і об'єктивність - основні вимоги, що пред'являються до юристів, які розробляють закони. Суттєве значення мають також уміння працювати в команді і чути аргументи опонентів, здатність адаптуватися до умов, що змінюються, і пропонувати альтернативні рішення, а також такі якості, як терпимість, психологічна стійкість, а часом навіть і фізична витривалість. Загальновідомо, що проходження законопроекту та доопрацювання його тексту - найчастіше тривалий і істотно непередбачуваний процес.

Необхідно пам'ятати, що законотворчість - це своєрідна технологія. Вміння писати закони залежить не стільки від здатності і таланту його розробників, скільки від того, наскільки відповідні особи оволоділи професійними навичками, методиками та практичними прийомами розробки нормативного змісту і юридико-технічного оформлення тексту закону. Насамперед йдеться про способи словесного вираження правових приписів, зовнішнього оформлення і внутрішнього побудови нормативних актів. Крім того, в будь-якій державі $є$ певні правила і технічні прийоми, використання яких дає змогу правильно сформулювати правові дефініції та юридичні конструкції, знайти оптимальні способи викладу правових приписів, домогтися доступності та лаконічності юридичного тексту, узгодити зміст і форму законопроекту з іншими законодавчими актами. Правила складання нормативно-правових документів можуть варіюватися залежно від виду акта, однак загальні вимоги юридичної техніки єдині.

Таким чином, законотворчість, як і будь-який інший вид професійної діяльності, передбачає засвоєння загальних правил, спеціальних прийомів $\mathrm{i}$ методик, пов'язаних із розробкою нормативного змісту і оформленням законопроекту, які напрацьовуються і вдосконалюються в процесі правотворчості. Разом із тим ступінь досконалості закону, його якість, зрештою, визначається професійним чуттям і творчим потенціалом його розробників. Ще у XVIII ст. французький просвітитель Ш. Монтеск'є у праці «Про дух законів» зазначав, що у процесі напрацювання законів мають бути враховані правила: 
- зміст законів має бути стислим і простим; прямі висловлювання завжди є доступнішими, ніж вишукані;

- слова закону мають розумітися однаково різними людьми ${ }^{3}$.

Відомий американський філософ права Л. Фуллер обгрунтував формальні вимоги до законодавчих норм, згідно з якими вони мають:

- бути ясно сформульовані (зрозумілі адресату);

- бути стабільними (не наражатися занадто частим і необгрунтованим змінам) $)^{4}$.

Свропейські фахівці у сфері розробки законів акцентують на тому, щоб формулювання правових приписів законопроекту забезпечували дотримання принципу правової визначеності, який передбачає стабільність правового регулювання та наявних правовідносин. Відповідно до цього принципу закон трактується Європейським Судом із прав людини як якісний, якщо він доступний для зацікавлених осіб, точно і конкретно сформульований і не суперечить принципу верховенства права ${ }^{5}$. Однією 3 принципових вимог до розробки якісного закону $\epsilon$ повага авторами законопроекту легітимних інтересів тих, на кого цей закон буде поширюватися в разі прийняття. Свропейська Комісія «За демократію через право» (Венеціанська Комісія) на 86-му пленарному засіданні 25-26 березня 2011 року у Доповіді «Верховенство права» вказала, що основними критеріями розуміння верховенства права $\epsilon$, зокрема, доступність закону (в тому значенні, що закон має бути зрозумілим, чітким та передбачуваним $)^{6}$.

Багато проблем, що випливають 3 якості законів, породжують питання, пов'язані з їх ефективністю і можливістю застосування. На жаль, як показує українська практика, розробники закону не завжди належною мірою прораховують політичні, правові, економічні та соціальні наслідки прийняття відповідного акта. Тому завдання будь-якого розробника закону - оптимально «вписати» його в чинну правову систему, мінімізувати двозначність i неоднозначність формулювань, усунути внутрішні протиріччя і прогалини, які можуть породити проблеми і складнощі в процесі його застосування.

\footnotetext{
${ }^{3}$ Общая теория государства и права. Академический курс в трех томах / отв. ред. М.Н. Марченко. 3-е изд., перераб. и доп. Москва : Норма, 2007. 803 с.

${ }^{4}$ Фуллер Лон Л. Мораль права : Наукове видання / пер. з англ. Н. Комарова. Київ : Сфера, 1999. 232 с.

5 Стандарты Совета Европы в области прав человека применительно к положениям Конституции Российской Федерации : избранные права / Науч. ред. Н.В. Варламова, Т.А. Васильева. Москва : Институт права и публичной политики, 2002. 606 с.

${ }^{6}$ Верховенство права : Доповідь Європейської комісії (Венеціанська комісія) «За демократію через право» від 25-26.03.2011. URL: https://www. venice.coe.int/webforms/documents/default.aspx?pdffile=CDL$\mathrm{AD}(2011) 003 \mathrm{rev}-\mathrm{ukr}$ (дата звернення: 04.05.2020).
} 
Таким чином, можна зробити короткий висновок: однією 3 основних вимог, що висувається до законотворчої техніки і мови, є його ясність. Закон має бути доступним для населення, що досягається простотою словарного запасу, яким користується законодавець. Щоб закон виконувався, він має бути доступним усім, на кого поширюється. Вживання спеціально-юридичних термінів і понять дає змогу сформулювати закон точно i коротко. Точність законодавчого тексту має дуже важливе значення. Закон має висловлювати думку, ідею, прагнення законотворця максимально точно, виключаючи подвійне тлумачення і спотворення. Тобто зрозумілість, точність, кратність мови закону створюють сприятливі умови для однакового його розуміння і тлумачення, однакового його дотримання, виконання і застосування, що загалом сприятиме режиму правопорядку в державі ${ }^{7}$.

Громадяни України реалізують своє конституційне право брати участь в управлінні державними справами (ст. 38 Конституції України), в тому числі у прийнятті державних рішень, включаючи участь у розробці законопроектів. Закріплення цього права в Конституції України повністю відповідає міжнародним нормам, зокрема, передбаченому у п. «а» ст. 25 «Міжнародного пакту про громадянські і політичні права» положенню про право кожного громадянина без будь-якої дискримінації та без обгрунтованих обмежень брати участь у веденні державних справ як безпосередньо, так і за посередництвом вільно обраних представників ${ }^{8}$.

3 огляду на зазначене вище можна констатувати, що нині в Україні створено правове підгрунтя для належної діяльності відповідних державних інституцій, що дає їм змогу приймати якісні нормативноправові акти (закони). Однак, як зазначалося вище, в Україні склалася така правова реальність у правотворчій та правозастосовній діяльності, яка не відповідає зазначеним теоретико-правовим напрацюванням і що своєю чергою дає підстави говорити про наявність в Україні загроз і небезпек національному праву.

\section{2. Характерні ознаки викликів правовій безпеці суспільства}

В Україні на нинішньому етапі іiі розвитку можна виділити такі напрями згаданих загроз і небезпек для правової безпеки суспільства.

По-перше, це поспішність, з якою готуються і приймаються закони. Вже не один рік керівництво парламенту відповідного скликання прагне

\footnotetext{
${ }^{7}$ Общая теория государства и права. Академический курс в трех томах / отв. ред. М.Н. Марченко. 3-е изд., перераб. и доп. Москва : Норма, 2007. 803 с.

8 Міжнародний пакт про громадянські і політичні права від 16 грудня 1966 року, прийнятий Генеральною Асамблеєю ООН. URL : https://zakon.rada.gov.ua/ laws/show/995_043 (дата звернення: 24.04.2020).
} 
показати свою роботу з напрацювання законів більш насиченою порівняно 3 попереднім скликанням. Однак ця робота полягає в основному у внесенні змін до чинних законів, а потім - змін до законів 3 уже внесеними попередніми змінами. Часто ці зміни мають технічний характер або ж, як показує практика, відповідають вузькокорпоративним інтересам.

Якщо проаналізувати аналогічну роботу парламенту III-го скликання за 1999-2002 роки, то маємо такі дані: у 1999 році, відповідно, 131 - внесення змін, 76 нових законів; 2000 рік: 121 - внесення змін, 89 нових законів; 2001 рік: 113 - внесення змін, 67 нових законів. Співвідношення прийнятих нових законів до законів про внесення змін становить 1 до 1,4-1,7.

Своєю чергою парламентом VIII-го скликання у 2017 році було прийнято 151 закон, не враховуючи законів про ратифікацію міжнародних угод. Із зазначеної кількості 123 - внесення змін до законів, 28 - нові закони; у 2018 році, відповідно, 131 закон, з яких 104 - внесення змін, 27 нові закони; за останню сесію в 2019 році - 26 законів, з яких 22 - про внесення змін, 4 - нові закони. Співвідношення нових законів до законів про внесення змін становить 1 до 4.

Парламентом IX скликання за коротку 1-у і 2-у сесії 2019 року в процесі так званого «турборежиму» прийнято 125 законів, 3 яких 111 - про внесення змін, 14 - нові закони; за неповну 3-ю сесію 2020 року 29 законів, 3 яких 26 - про внесення змін, 3 - нові закони. Відповідне співвідношення становить 1 до 8.

По-друге, 3 точки зору фахівця права, який у парламенті протягом II-VIII скликання пропрацював у багатьох робочих групах, що створювалися парламентом із напрацювання законопроектів, зазначу: якщо раніше законопроект являв собою комплексне напрацювання на підставі наукової, практичної та політичної думки щодо врегулювання відповідних відносин у тій чи іншій сфері життєдіяльності суспільства, то сказати зазначене про більшість нинішніх законопроектів не можна.

Тенденція щодо переважання вузько-корпоративних інтересів над загальносуспільними, які відображуються у змісті законопроектів, набула чітких рис у сучасних законопроектах i прийнятих законах. До напрацювання таких законопроектів практично не залучаються наукове середовище і громадянське суспільство, що викликає загострення відносин між владою і суспільством. Так, за III-е скликання співвідношення законопроектів, розроблених органами виконавчої влади, і законопроектів, розроблених народними депутатами України, становить 5 до 1, у VIII-y скликанні - 1 до 16, а на початку нинішнього IX-го скликання - 1 до 7.

Для прикладу зазначеного вище можна навести кричущий факт щодо невиплати Урядом належних пенсій колишнім військовим та іншим особам 
сектора безпеки і оборони. Зазначена категорія осіб вже десятки років за період незалежності України бореться за своє право отримувати належну їм пенсію. Однак Уряд під різними приводами не лише прагне не виплачувати їм належну пенсію, але й намагається непрозоро, без залучення ветеранської спільноти i науковців напрацювати новий, складний i незрозумілий більшості військових пенсіонерів пенсійний закон, на зразок такого ж незрозумілого для більшості пенсіонерів України Закону України «Про загальнообов'язкове державне пенсійне страхування» ${ }^{9}$ Тим самим, всупереч внутрішнім директивним документам та взятим Україною на себе зобов'язанням щодо надання громадянам доступу до управління державними справами та напрацювання управлінських рішень, публічна влада прагне нетранспарентно, без залучення громадськості внести зміни у правовий механізм регулювання суспільних відносин у сфері пенсійного забезпечення. На неодноразові звернення ветеранських організацій до влади з пропозиціями співпраці у цій сфері, у відповідь - лише обіцянки або мовчання. I лише широкі соціальні протести 3 пікетуванням органів публічної влади не дають змогу згаданому бути реалізованим, тобто свідомо погіршити регулюючий правовий механізм для відповідної категорії громадян, який їх повністю влаштовує.

Зазначене вище продовжується і нині, що підтверджується, наприклад, у публіцистичних джерелах: «Всім добра за ваші гроші : одіозні законопроекти від нардепів» ${ }^{10}$, що свідчить, наскільки малозмістовними та економічно безграмотними можуть бути депутатські пропозиції. Іноді депутатські правки, які парламентарі оформляють у вигляді законопроектів, перекреслюють зміни, до яких країна йшла роками. Так, у цих актах відсутні фінансові обгрунтування запропонованих змін, запропоновані ними пільги порушують правило рівності всіх платників податків, відсутні пропозиції щодо скорочення витрат бюджету або пошуку додаткових джерел надходжень; фінансові розрахунки депутати, як правило, не надають; після ухвалення парламентом майже кожного важливого закону його пропонують скасувати; часто проявляється алогічність системи правових норм у запропонованих актах тощо. Під виглядом законотворчої активності фактично напрацьовується законодавчий спам.

I був би не таким страшним прийнятий згаданий спам, як і ухвалене судом неправосудне рішення, якби за ними не проглядалися різні долі наших громадян. Так, відповідно до ст.ст. 263, 263-1 Кримінального

\footnotetext{
9 Про загальнообов'язкове державне пенсійне страхування : Закон України від 09.07.2003 р. № 1058-IV. Відомості Верховної Ради Украӥни. 2003. №№ 49-51. Ст. 376.

${ }^{10}$ Всім добра за ваші гроші : одіозні законопроекти від нардепів. URL : https://www.epravda.com.ua/ projects/regulation/2020/04/22/659618/ (дата звернення: 29.04.2020).
} 
кодексу України (ККУ) ${ }^{11}$ передбачена кримінальна відповідальність за незаконне поводження зі зброєю, бойовими припасами або вибуховими речовинами та незаконне виготовлення, переробку чи ремонт вогнепальної зброї або фальсифікацію, незаконне видалення чи зміну іiі маркування, або незаконне виготовлення бойових припасів, вибухових речовин чи вибухових пристроїв. За різними даними за 2007-2016 рр. в Україні до кримінальної відповідальності лише за ст. 263 ККУ було притягнуто 52011 осіб.

Таким чином, у державі має функціонувати закон, положенням якого регулювалися б згадані питання і за порушення яких громадяни несли б зазначену відповідальність відповідно до ККУ. Однак такий закон в Україні відсутній, хоча робилися неодноразові спроби його розробити i прийняти. Цілком логічним $є$ питання: за яких правових підстав, за відсутності відповідного закону, громадян притягують до кримінальної відповідальності?

Ще зовсім недавно (вирок від 19.02.2018 р.) Печерський районний суд, виправдовуючи підсудного у справі № 757/7651/16-к, зазначив, що держава не вправі застосовувати до особи процесуальний примус у вигляді кримінальної відповідальності за відсутність дозволу, передбаченого законом, поки немає закону, який передбачає отримання цього дозволу ${ }^{12}$. І зазначене, на наше переконання, $є$ цілковитою правовою позицією суду, оскільки відповідає загальновизнаній правовій засаді «nullum crimen sine lege» (немає злочину і покарання без наперед установленого закону). Зазначений принцип закріплений в ст. 7 Міжнародної Конвенції ${ }^{13}$ : «Нікого не може бути визнано винним у вчиненні будь-якого кримінального правопорушення на підставі будь-якої дії чи бездіяльності, яка на час іiі вчинення не становила кримінального правопорушення згідно 3 національним законом або міжнародним правом».

Однак 31 травня 2018 р. колегія суддів Другої судової палати Касаційного кримінального суду Верховного Суду у своїй постанові (справа № 127/27182/15-к, провадження № 51-3305км18) зазначила, що поняття «закон», вжите законодавцем у ст. 263 КК, має розширене тлумачення і включає законодавство загалом, у тому числі нормативні

11 Кримінальний кодекс України від 05.04.2001 р. № 2341-III. Відомості Верховної Ради Украйни. 2001. № 25-26. Ст. 131 .

${ }^{12}$ Відсутність закону щодо порядку надання дозволу на носіння зброї не унеможливлює притягнення особи до кримінальної відповідальності (ВС/ККС, справа №127/27182/15-к, 31.05.18). URL: https://protocol.ua/ru/vs_kks_vidsutnist_zakonu_shchodo_poryadku_nadannya_dozvolu_na_nosinnya_zbroi_ne _unemoglivlyue_prityagnennya_osobi_do_kriminalnoi_vidpovidalnosti_(vs_kks_sprava/_дата звернення: $\overline{0} 1.05 .2020)$.

13 Конвенція про захист прав людини і основоположних свобод від 04.11.1950 p. URL: https://zakon.rada.gov.ua/laws/show/995_004 (дата звернення: 01.05.2020). 
акти, що регулюють відповідні правовідносини, порушення яких утворює об’єктивну сторону складу злочину, передбаченого цією статтею кримінального закону. Під розширеним поняттям «закон» Верховний Суд має на увазі відповідний наказ Міністерства внутрішніх справ України ${ }^{14}$, прийнятий на підставі Закону України «Про міліцію», який втратив чинність 02.07.2015 p.

На нашу думку, позиція Суду є хибною.

По-перше, об'єктивна сторона злочину за ст.ст. 263, 263-1 ККУ полягає в незаконному поводженні зі зброєю, бойовими припасами або вибуховими речовинами» та незаконному виготовленні, переробці чи ремонті вогнепальної зброї або фальсифікації, незаконному видаленні чи зміні ii маркування, або незаконному виготовленні бойових припасів, вибухових речовин чи вибухових пристроїв. Таким чином, законодавець визначив функціонування (наявність) закону, предметом регулювання якого є регулювання суспільних відносин, пов'язаних із зазначеним вище, $\mathrm{i}$ яким передбачено отримання дозволу на згадане, тобто призначення закону полягає у здійсненні регулятивної функції. Своєю чергою, відповідно до ч. 2 ст. 178 Цивільного кодексу України ${ }^{15}$, «види об’єктів цивільних прав, перебування яких у цивільному обороті не допускається (об’єкти, вилучені з цивільного обороту), мають бути прямо встановлені в законі. Види об'єктів цивільних прав, які можуть належати лише певним учасникам обороту або перебування яких у цивільному обороті допускається за спеціальним дозволом (об'єкти, обмежено оборотоздатні), встановлюються законом».

Основна ж функція кримінального права - це охоронна функція. Саме кримінальне право через ККУ покликано стояти на сторожі найважливіших суспільних відносин від їх порушення, застосовувати до винних найсуворіші заходи примусу - покарання. Як зазначає відомий науковець П. Фріс ${ }^{16}$, кримінальне право, охороняючи нормами Особливої частини ККУ суспільні відносини, не регулює їх, а для визначення факту порушення в низці випадків відсилає через банкетну норму до

\footnotetext{
14 Про затвердження Інструкції про порядок виготовлення, придбання, зберігання, обліку, перевезення та використання вогнепальної, пневматичної, холодної і охолощеної зброї, пристроїв вітчизняного виробництва для відстрілу патронів, споряджених гумовими чи аналогічними за своїми властивостями метальними снарядами несмертельної дії, та патронів до них, а також боєприпасів до зброї, основних частин зброї та вибухових матеріалів : наказ Міністерства внутрішні справ України від 21.08.1998 p. № 622. URL: https://zakon.rada.gov.ua/laws/show/z0637-98 (дата звернення: 01.05.2020).

${ }^{15}$ Цивільний кодекс України від 16.01.2003 р. № 435-IV. Відомості Верховної Ради Украӥни. 2003. № № 40-44. Ст. 356.

${ }^{16}$ Щодо кримінальної відповідальності за незаконне поводження зі зброєю, бойовими припасами або вибуховими речовинами (ст. 263 КК України). URL: https://lexinform.com.ua/yuridychna-praktyka/shhodokryminalnoyi-vidpovidalnosti-za-nezakonne-povodzhennya-zi-zbroyeyu-bojovymy-prypasamy-abovybuhovymy-rechovynamy-st-263-kk-ukrayiny/ (дата звернення: 02.05.2020).
} 
регуляторних актів інших галузей права, у цьому випадку до закону, якого немає. Своєю чергою Конституційний Суд України зазначає, що бланкетна диспозиція кримінально-правової норми лише називає або описує злочин, а для повного визначення його ознак відсилає до інших галузей права ${ }^{17}$.

По-друге, тлумачення Судом терміна «закон» у широкому сенсі, що включає усі нормативно-правові акти публічної влади, не відповідає положенням загальної теорії держави $\mathrm{i}$ права i національному законодавству. Закон є творінням законодавчої влади. В Україні використовується в широкому сенсі термін «законодавство», але не «закон», оскільки в країні не запроваджено делеговане законодавство, як це передбачено в конституціях багатьох європейських країн. Як зазначає суддя Конституційного суду України В. Кампо ${ }^{18}$, в Конституції Італії 3 1947 року передбачено, що здійснення законодавчих функцій парламенту може бути делеговано уряду. Аналогічні конституційні положення є в конституціях Іспанії 1978 року, Франції 1958 року, Великобританії. В Україні досвід застосування такого інституту був у Президента України Л. Кучми у 1990-х роках. Лише в окремих федеративних державах (Австрія, Бельгія, Федеративна Республіка Німеччина, Швейцарія, Російська Федерація) поряд із «федеральним законом» використовується вираз «закони учасника федерації», які мають назви, такі як «декрети» або «постанови». Федеральний закон та закон учасника федерації мають однаковий статус. Однак у деяких федеративних державах «федеральний закон має перевагу над кантональним правом».

Таким чином, вищезазначене дає підстави констатувати факт відсутності нині в Україні закону, що здійснює регуляцію суспільних відносин у сфері обороту зброї, боєприпасів та вибухових речовин, що своєю чергою не дає змоги визначати законність чи незаконність тих чи інших дій із зазначеними предметами. Тим не менш органи досудового розслідування продовжують реєструвати кримінальні провадження та здійснювати попереднє розслідування, а суди - виносити обвинувальні вироки за ст.ст. 263, 263-1 КК України. При цьому вони посилаються на порушення особами порядку обороту цих предметів, врегульованого підзаконними актами.

Викликає, м'ягко кажучи, подив твердження Суду, що законодавець, використовуючи термін «закон», мав на увазі його розширене тлумачення -

\footnotetext{
17 Рішення Конституційного Суду України у справі за конституційним поданням 46 народних депутатів України щодо офіційного тлумачення положень статті 58 Конституції України, статей 6, 81 Кримінального кодексу України (справа про зворотну дію кримінального закону в часі) від 19.04.2000 p. № 6-pп/2000. URL: https://zakon.rada.gov.ua/laws/show/v006p710-00 (дата звернення: 02.05.2020).

18 Делеговане законодавство в Україні : що, як і чому? Юридична Газета online. URL: https://yurgazeta.com/dumka-eksperta/delegovane-zakonodavstvo-v-ukrayini-shcho-yak-i-chomu.html (дата звернення: 02.05.2020).
} 
законодавство загалом. Зазначене $\epsilon$ перекручуванням термінологічного змісту з певним умислом (можливо, будь-якою метою заповнити вакуум правового регулювання цієї сфери), оскільки законодавець чітко знає свої повноваження щодо врегулювання суспільних відносин шляхом прийняття ним законів, як це і передбачено Конституцією України.

Таким чином, притягнення особи до кримінальної відповідальності у згаданих випадках грубо порушує Конституцію України, і влада не вправі застосовувати до особи процесуальний примус у вигляді кримінальної відповідальності. Крім того, термінологічні маніпуляції з метою надання вироку певного вигляду законності - це прийняття завідомо неправосудного рішення і створення великої загрози правовій безпеці суспільства.

Оскільки вимоги, що висуваються до обсягу наукової статті, не дають змоги наводити інші приклади прояву загроз правовій безпеці суспільства, згадаємо лише коротко відповідні факти (виклики), що підтверджують зазначене:

- дострокове припинення повноважень парламенту України, ухвалене Президентом України на підставі рішення Конституційного Суду України у справі за конституційним поданням 62 народних депутатів України щодо відповідності Конституції України (конституційності) Указу Президента України «Про дострокове припинення повноважень Верховної Ради України та призначення позачергових виборів» від 20.06.2019 р. № 6-p/2019 ${ }^{19}$, яке неоднозначно сприйняте в науковому та суспільному середовищах, оскільки прийняте не на підставі фактичних правових підстав, а внаслідок прийняття політико-правового рішення 3 метою розв'язання конституційного конфлікту між Президентом України та Верховною Радою України, до виникнення якого спонукала прогалина в законодавстві щодо початку перебігу місячного терміну формування нової коаліції депутатських фракцій;

- правова прогалина в КК України, яка виникла після прийняття рішення Конституційного Суду України у справі за конституційним поданням 59 народних депутатів України щодо відповідності Конституції України (конституційності) ст. 368-2 Кримінального кодексу України від 26.02.2019 № 1-p/2019²0 щодо незаконного збагачення, до прийняття

\footnotetext{
19 Рішення Конституційного Суду України у справі за конституційним поданням 52 народних депутатів України щодо відповідності Конституції України (конституційності) Указу Президента України «Про дострокове припинення повноважень Верховної Ради України та призначення позачергових виборів» від 20.06.2019 р. № 6-p/2019. URL: http://www.ccu.gov.ua/dokument/6-r2019 (дата звернення: 04.05.2020).

20 Рішення Конституційного Суду України у справі за конституційним поданням 59 народних депутатів України щодо відповідності Конституції України (конституційності) статті $362-2$
} 
нової ст. 368-5 в КК України, внаслідок чого відкриті кримінальні провадження за згаданою статтею були закриті. На думку багатьох громадян, зазначене є своєрідною амністією для «злодіїв від влади». Зазначене рішення теж неоднозначно сприйняте в науковому та суспільному середовищах, оскільки Конституційний Суд України міг скористатися своїм правом відтермінувати дату втрати чинності ст. 368-2 КК України, яке надають йому приписи ст. 91 Закону України «Про Конституційний Суд України». 3 цим пов'язана також не використана змога рекомендувати Верховній Раді України уточнити законодавче формулювання складу вказаного злочину з урахуванням юридичних позицій Конституційного Суду України;

- відпущення під грошову заставу осіб, які скоїли тяжкі злочини, включаючи убивства, на підставі непоодиноких рішень судів. Наслідками $\epsilon$ втрата віри громадян на винесення справедливого вироку за вчинений злочин, зниження довіри до судів, суддів і загалом до влади;

- однією з основних структурних проблем політичної системи в Україні $\epsilon$ фактична монополізація доступу до державного управління обмеженим колом осіб - групами монопольного економічного впливу (частіше вживаними в Україні $є$ визначення «олігархи» або «олігархічні групи»). Чинні демократичні механізми (наприклад, вибори, референдуми) традиційно використовуються олігархічними групами як інструменти для досягнення власних цілей та боротьби одна 3 одною. Суспільні та політичні інститути (політичні партії, 3МI, профспілки, недержавні громадські організації тощо) є занадто слабкими або фінансово залежними від олігархічних груп, щоби скласти їм ефективну конкуренцію в боротьбі за вплив на процеси ухвалення рішень у країні. 32018 року відсутнє законодавче регулювання організації та проведення загальноукраїнського референдуму, а з 2012 року - місцевих референдумів. Тим самим нині відсутні законодавчі механізми реалізації конституційного права громадян брати участь як у всеукраїнському, так і в місцевих референдумах. А народне волевиявлення зводиться лише до змоги брати участь у виборах. Зазначене викликає в суспільстві зневіру в реалізації принципу народовладдя, демократизації суспільного життя тощо;

- існування в країні надзвичайно високого рівня корупції, що пояснюється відсутністю для цього політичної волі керівництва держави; неналежна кадрова політика, яка була б спрямована на очищення влади від корупціонерів; супротив представників публічної влади запровадженню дієвого контролю з боку громадянського суспільства й незалежних засобів

Кримінального кодексу України від 26.02.2019 р. № 1-p/2019. URL: https://zakon.rada.gov.ua/laws/show/ v001p710-19 (дата звернення: 04.05.2020). 
масової інформації. Так, як повідомляє голова експертної організації StateWatch Гліб Канєвський із посиланням на лист Державної казначейської служби, за перші три місяці 2020 року до державного бюджету надійшло 14 тис. грн від реалізації майна, а також коштів, конфіскованих за вчинення корупційних та пов'язаних із корупцією правопорушень ${ }^{21}$. Про зазначене свідчить i те, що групою народних депутатів внесено на розгляд Верховної Ради законопроект ${ }^{22}$, мета якого дозволити чиновникам не показувати в деклараціях позашлюбних дітей. Головна ціль законопроєкту - дозволити не декларувати майно неповнолітніх дітей, які не живуть із батьками-декларантами, за чим криються корупційні ризики, пов'язані з приховуванням майна чиновників, якщо воно записане на неповнолітніх дітей.

\section{ВИСНОВКИ}

Зазначені вище негативні факти свідчать про наявність в Україні загроз українському суспільству у сфері національного права, тобто загроз правовій безпеці суспільства. Тому для подальшого розвитку України в частині розбудови громадянського суспільства, яке в правовому плані буде захищеним та буде ефективно розвиватися, держава має орієнтуватися на європейські стандарти забезпечення та захисту прав і свобод людини та суспільства, зокрема впровадження практики належного врядування, доброчесності, відкритості, прозорості та підзвітності інститутів влади, створення умов для різноманіття суспільних інтересів, у тому числі економічних, екологічних, соціальних, культурних, релігійних, територіальних тощо і форм їх вираження.

Таким чином, поглиблення соціальної спрямованості правової системи України нерозривно пов'язане із соціокультурними чинниками, зростанням правової культури та правової свободи для суспільства, подоланням гіперіндивідуалізму, підвищенням соціальної і правової етики, недопущенням такого ганебного явища в нормотворчій діяльності в Україні, як замовна законотворчість у вузькокорпоративних інтересах.

Має бути забезпечена реальна захищеність життєво важливих інтересів суспільства, якими є демократичні цінності, тобто змога за допомогою права визначати свої політичні, економічні, соціальні та культурні системи, правове забезпечення та брати активну участь у вирішенні

\footnotetext{
21 За перший квартал у корупціонерів конфіскували 14 тисяч гривень - Держказначейство. URL: https://www.epravda.com.ua/news/2020/04/17/659511/ https://zakon.rada.gov.ua/laws/show/v001p710-19 (дата звернення: 06.05.2020).

22 У Раду внесли закон, який дозволить чиновникам ховати позашлюбних дітей. URL: https://www.pravda.com.ua/news/2020/05/5/7250497/ (дата звернення: 06.05.2020).
} 
питань, що стосуються життя у всій різноманітності його вимірів, добробуту та умов для свого сталого розвитку.

\section{АНОТАЦІЯ}

У статті досліджується питання наявних та потенційних викликів (загроз i небезпек) праву, що регулює функціонування суспільства, i що, відповідно до концепції правової безпеки, є загрозами правовій безпеці суспільства в Україні. Зазначено, що одним із таких викликів залишається низька, за певним виключенням, активність громадян у громадському житті, що негативно впливає на становлення демократії в Україні.

Констатується, що аналіз положень системи національного права в Україні у процесі його реформування свідчить, що вони загалом направлені на утвердження в Україні головних принципів народовладдя. Водночас об'єктивні факти суспільного життя в Україні дають підстави стверджувати, що дотримання права в українському суспільстві та державі знаходиться в неналежному стані, а це вказує на проблеми зі станом правової безпеки суспільства.

На думку автора, в Україні є вагомі підстави стверджувати, що рівень законності, правозастосування, правосвідомості українського суспільства, включаючи посадових і службових осіб публічної влади, не відповідає зазначеному у ст. 1 Конституції щодо правового, соціального та демократичного статусу держави, підтвердженнями чого, своєрідним лакмусовим папірцем, $є$ високий рівень корупції, глибоке соціальне розшарування населення в державі, рекордна кількість скарг українських громадян до Європейського суду щодо порушень їхніх прав із боку державної влади.

Причиною є те, що в останні десять років в Україні склалася певна негативна ситуація у сфері законотворчої діяльності. Як показує українська практика, розробники закону не завжди належною мірою прораховують політичні, правові, економічні та соціальні наслідки прийняття відповідного акта, що пов'язано 3 поспішністю, 3 якою готуються і приймаються закони, а також із тенденцією щодо переважання вузько-корпоративних інтересів над загальносуспільними, які відображуються в змісті законопроектів.

Робиться висновок про необхідність забезпечення реальної захищеності життєво важливих інтересів суспільства, якими є демократичні цінності, тобто змогу за допомогою права визначати свої політичні, економічні, соціальні та культурні системи, а також брати участь у вирішенні питань, що стосуються життя у всій різноманітності його вимірів, добробуту та умов для сталого розвитку суспільства. 


\section{ЛІТЕРАТУРА:}

1. Велика українська юридична енциклопедія : у 20 т. / ред. кол. : О.В. Петришин (голова) та ін.; Нац. акад. прав. наук України; Ін-т держави і права імені В.М. Корецького НАН України; Нац. юрид. ун-т імені Ярослава Мудрого. Харків, 2017. Т. 3 : Загальна теорія права. 952 с.

2. Конституція України від 26.06.1996 р. Відомості Верховної Ради Украӥни. 1996. № 30. Ст. 141.

3. Монтескье Ш. Избранные произведения. Москва : Госполитиздат, $1955.803 \mathrm{c}$.

4. Фуллер Лон Л. Мораль права : Наукове видання / пер. 3 англ. Н. Комарова. Київ : Сфера, 1999. 232 с.

5. Стандарты Совета Европы в области прав человека применительно к положениям Конституции Российской Федерации : избранные права / Науч. ред. Н.В. Варламова, Т.А. Васильева. Москва : Институт права и публичной политики, 2002. 606 с.

6. Верховенство права : Доповідь Свропейської комісії (Венеціанська комісія) «За демократію через право» від 25-26.03.2011 p. URL : https://www.venice.coe.int/webforms/documents/default.aspx?pdffile=CDL$\mathrm{AD}$ (2011)003rev-ukr (дата звернення: 04.05.2020).

7. Общая теория государства и права. Академический курс в трех томах / отв. ред. М.Н. Марченко. 3-е изд., перераб. и доп. Москва : Норма, 2007. $803 \mathrm{c}$.

8. Міжнародний пакт про громадянські і політичні права від 16 грудня 1966 p., прийнятий Генеральною Асамблеєю OOH. URL: https:// zakon.rada.gov.ua/ laws/show/995_043 (дата звернення: 24.04.2020).

9. Про загальнообов'язкове державне пенсійне страхування : Закон України від 09.07.2003 р. № 1058-IV. Відомості Верховної Ради України. 2003. №№ 49-51. Ст. 376.

10. Всім добра за ваші гроші : одіозні законопроекти від нардепів. URL: https://www.epravda.com.ua/projects/regulation/2020/04/22/659618/ (дата звернення: 29.04.2020).

11. Кримінальний кодекс України від 05.04.2001 p. № 2341-III. Відомості Верховної Ради України. 2001, № 25-26, ст. 131.

12. Відсутність закону щодо порядку надання дозволу на носіння зброї не унеможливлює притягнення особи до кримінальної відповідальності (BC/ККС, справа № 127/27182/15-к, 31.05.18). URL: https://protocol.ua/ru/ vs_kks_vidsutnist_zakonu_shchodo_poryadku_nadannya_dozvolu_na_nosinnya _zbroi_ne_unemoglivlyue_prityagnennya_osobi_do_kriminalnoi_vidpovidalnos ti_(vs_kks_sprava/ (дата звернення: 01.05.2020). 
13. Конвенція про захист прав людини і основоположних свобод від 04.11.1950 p. URL: https://zakon.rada.gov.ua/laws/show/995_004 (дата звернення: 01.05.2020).

14. Про затвердження Інструкції про порядок виготовлення, придбання, зберігання, обліку, перевезення та використання вогнепальної, пневматичної, холодної і охолощеної зброї, пристроїв вітчизняного виробництва для відстрілу патронів, споряджених гумовими чи аналогічними за своїми властивостями метальними снарядами несмертельної дії, та патронів до них, а також боєприпасів до зброї, основних частин зброї та вибухових матеріалів : Наказ Міністерства внутрішні справ України від 21.08.1998 р. № 622. URL: https://zakon.rada.gov.ua/laws/show/z0637-98 (дата звернення: 01.05.2020).

15. Цивільний кодекс України від 16.01.2003 p. № 435-IV. Вiдомості Верховної Ради України. 2003. № № 40-44. Ст. 356.

16. Щодо кримінальної відповідальності за незаконне поводження зі зброєю, бойовими припасами або вибуховими речовинами (ст. 263 КК України). URL: https://lexinform.com.ua/yuridychna-praktyka/shhodokryminalnoyi-vidpovidalnosti-za-nezakonne-povodzhennya-zi-zbroyeyubojovymy-prypasamy-abo-vybuhovymy-rechovynamy-st-263-kk-ukrayiny/ (дата звернення: 02.05.2020).

17. Рішення Конституційного Суду України у справі за конституційним поданням 46 народних депутатів України щодо офіційного тлумачення положень статті 58 Конституції України, статей 6, 81 Кримінального кодексу України (справа про зворотну дію кримінального закону в часі) від 19.04.2000 p. № 6-pп/2000. URL: https://zakon.rada.gov.ua/laws/show/ v006p710-00 (дата звернення: 02.05.2020).

18. Делеговане законодавство в Україні : що, як і чому? Юридична Газета online. URL: https://yur-gazeta.com/dumka-eksperta/delegovanezakonodavstvo-v-ukrayini-shcho-yak-i-chomu.html (дата звернення: 02.05.2020).

19. Рішення Конституційного Суду України у справі за конституційним поданням 52 народних депутатів України щодо відповідності Конституції України (конституційності) Указу Президента України «Про дострокове припинення повноважень Верховної Ради України та призначення позачергових виборів» від 20.06 .2019 р. № 6-p/2019. URL: http:// www.ccu.gov.ua/dokument/6-r2019 (дата звернення: 04.05.2020).

20. Рішення Конституційного Суду України у справі за конституційним поданням 59 народних депутатів України щодо відповідності Конституції України (конституційності) статті 362-2 Кримінального кодексу України від 26.02.2019 р. № 1-p/2019. URL: https://zakon.rada.gov.ua/laws/show/ v001p710-19 (дата звернення: 04.05.2020). 
21. За перший квартал у корупціонерів конфіскували 14 тисяч гривень Держказначейство. URL: https://www.epravda.com.ua/news/2020/04/17/ 659511/ (дата звернення: 06.05.2020).

22. У Раду внесли закон, який дозволить чиновникам ховати позашлюбних дітей. URL: https://www.pravda.com.ua/news/2020/05/5/ 7250497/ (дата звернення: 06.05.2020).

\section{Information about author:} Korzh I. F., Doctor of Law Sciences, Senior Research Fellow, Head of the Scientific Laboratory Research Institute of Informatics and Law of the National Academy of Legal Sciences of Ukraine 110-v, Saksaganskogo str., Kyiv, Ukraine 